\title{
AN INVESTIGATION INTO THE FINANCIAL BARRIERS FACING WOMEN ENTREPRENEURS OPERATING IN SMMES IN TSHWANE, SOUTH AFRICA
}

\author{
Evelyn Chiloane-Tsoka* \\ University of South Africa \\ chiloge@unisa.ac.za
}

Received: March 2012

Accepted: May 2013

\begin{abstract}
The South African women emancipation policy statement and gender equality are critical tools established by government to eradicate poverty among entrepreneurs operating in small business. Khula was established to act as a financial wholesaler to emerging entrepreneurs who needed finance to start and grow businesses. The Small Enterprise Development Agency was established to provide training needs to small business operators. Lack of finance is a major stumbling block to women entrepreneurs reaching their full economic potential in South Africa. Financial collaterals are barriers for women operating in SMMEs in Tshwane. The objective of the study was to investigate the financial barriers facing women entrepreneurs in Tshwane when starting or growing businesses. In order to achieve the results a structured questionnaire and interviews were used as method of collecting data. A sample of 300 women operating SMMEs in six townships of the Tshwane metropolitan area was analysed per a quota of 50 businesses per township. The results indicate that women entrepreneurs lack the financial collateral that is demanded by financial institutions when applying for finance to start or grow their business.
\end{abstract}

Keywords

Entrepreneurship, women, financial collateral, financial institutions and SMMEs

*Prof G Evelyn Chiloane-Tsoka is professor in the Department of Business Management, University of South Africa, South Africa. 


\section{INTRODUCTION}

The Small Business Act No. 106 of 1996, as amended in 2003, was introduced to enable an environment conducive to small business, and medium and micro enterprises. The introduction of the policy statement declares the government's intention to promote the economic and social welfare of South African citizens through entrepreneurial and economic innovation and to stabilise economic opportunities. Since the advent of democracy, the South African government has been transforming all sectors for the benefit of disadvantaged South Africans. Women are part of the designated groups which needed government intervention. Women have not been active in the economic mainstream due to previous laws, which were gender insensitive.

The South African government, through its ministry of the Department of Trade and Industry (DTI), established the South African women entrepreneurship network (SAWEN) as a vehicle intended to provide mentorship and create more opportunities for women to speak with one voice in South Africa. The SAWEN mentorship programme's crucial aim is to liaise with women entrepreneurs and disseminate information on accessing finance to start and grow businesses. In a study conducted by Dollinger (1997:217), it was pointed out that women's difficulty in accessing capital is due to discrimination with respect to the collateral requirements of banks. The worst affected were black women, who were previously affected by discriminatory laws which made them minors, with no land that they could convert into cash. Thus, to redress the past, SAWEN was established in order to facilitate small business initiatives and Khula as a guarantee to financial institutions. Regrettably, the majority of African women use their pensions and social club donations in the form of stokvels as a way of starting their own businesses (Walker \& Joyner, 1999).

\section{BACKGROUND}

Entrepreneurial activity in South Africa, as captured in the GEM report of 2012, indicates that the Total Entrepreneurial Activity (TEA) of South Africa is only $9.1 \%$. This was arrived at by measuring the proportion of the country's adults (aged 18-64) who were involved in starting or running new businesses. According to Maas (2006) women still face financial barriers: banks are unwilling to provide capital to women entrepreneurs and this inhibits their business success when compared to their male counterparts. An important determinant of the level of black women entrepreneurs is the availability of finance and collateral for start-up businesses. Financial barriers are no doubt the greatest obstacle for women (Brush, 1992). In addition, the GEM report states clearly that women entrepreneurs provide all required start-up capital themselves, whilst their male counterparts, on the contrary, often list investors, bank loans, or personal loans in addition to personal funds as sources of start -up capital. According to Naidoo (2012) in GEM report of 2012, 5.6\% of South Africans discounted their businesses, although some factors of doing so are from positive motives such as retiring or changing business. Yet, some negative factors could be as a result of crime, education, infrastructure and funding. Furthermore, Naidoo articulated that finance is one of major obstacles hindering entrepreneurs. This finding confirms the findings by Maas (2006), in the GEM report.

In apartheid-era South Africa, the lack of financial support for black women was the consequence of segregation, which was also applied by the welfare system. The system of social protection was poor and it severely disadvantaged black women (Standing, Sender \& Weeks, 1996). The majority of these women were excluded from unemployment insurance as a result of 
membership specifications. Domestics and agricultural workers were also excluded from such benefits. Thus, the legal and economic positions of black women were precarious and insecure. Women bore the financial burden of caring for the young and the elderly (Budlender, 1991).

The fact that black women did not qualify to own property also limited their means of collateral and this placed further hardships and burdens on their starting businesses. The practical implications of the Land Act No. 27 of 1913 forced black women to seek economic opportunities elsewhere and pushed them into the informal sector, where they often engaged in beer-brewing.

Lack of access to credit is a typical first constraint inhibiting women from operating in the small, medium and micro enterprise sector. Even though credit cannot be regarded as a panacea, it is in turn a predictor of entrepreneurial success and can be used as a weapon for competition and curbs the selling to poor by the poor that has an adverse effect on survival incubators. The setback of lack of education is also a hindrance, since those who normally benefit in the SMMEs are those who enter the sector at a level of secondary rather than those at a primary level (King, 2003). Hendricks (2001) points out that another major problem could lie in the fact that most women who want to borrow money from banks do not have the necessary skill to formulate a professional business plan. Other studies on gender and business ownership have generated conflicting evidence on whether or not financing poses problems for women starting and running businesses. Sandberg (2003) identifies three areas of the financing process that have consistently been noted as posing particular problems for women:

Women may be at a disadvantage in their ability to raise start-up funds. Guarantees required for external financing may be beyond the scope of most women's personal assets and credit track record.

Finance for ongoing business costs may be less available for female-owned firms than for male enterprises, largely due to women's inability to penetrate informal financial networks.

Women entrepreneurs' relationships with bankers may suffer from sexual stereotyping and discrimination.

The situation in South Africa for the majority of black women entrepreneurs does not give them autonomy or satisfaction. The main feature of black women-owned businesses in small and micro enterprises is survival rather than autonomy and satisfaction, which in practice is associated with a high rate of failure. Those who practise business do not enjoy the support of financial institutions in any way that would unleash their potential to contribute to the economy. Although they have significant roles to play in the regeneration of the socioeconomically deprived communities in which they are mostly found, black business females are still oppressed (Mosala, 2003).

It should be noted that finance is not the only factor for women entrepreneurship. There are other factors such as illiteracy, being taken out of school at an early age, pregnancy, poverty, low status, lack of mentors, the multiple roles of child-rearing, concentration in low-levels of employment, as well as lack of autonomy and information access that further hinder women from reaching their full potential (Jiyane, 2002). The business activities in which the majority of black women participate are mainly in the informal sector, and include sewing, selling fruit and vegetables as street vendors, catering, and running shebeens, spaza shops and taverns. Their success in business thus cannot be judged using evidence of a stereotypical kind (Marlow, 1992).

It is argued that women in Uganda are in a similar position because their participation in the small business sector accounts for $90 \%$ as compared to $53 \%$ for men. Women labourers produce 
$80 \%$ of the country's food and $60 \%$ of traditional farm exports, such as coffee, cotton, sugar and tobacco as well as $80 \%$ of the non-traditional products (Elson \& Evers, 1997). Despite their significant participation in the Ugandan economy, their contribution is not fully utilised and they are marginalised. The reasons why they enter the small and informal sectors is to survive, ease of entry and low capital intensity and because it fits well with marriage and child-rearing (Besirika, 1994).

These situations are similar to the majority of black women in South Africa, especially in the rural areas because of lack of information that results from illiteracy and semi-illiteracy, and because they are very poor (Nwangha, 1996). In Nigeria those who participate in the small and informal sector are mostly divorced or widowed and head their households. They are extremely poor, are in the age bracket of 30-50 and have no access to land (0dongo, 2002). Ironically, the situation in Botswana is different. Women who participate in the small and informal sector are very few due to their educational background. Many women are educated and are able to access information in running their own businesses (Mchombu, 2000).

\section{CHALLENGES FACED BY BLACK WOMEN IN ACCESSING FINANCE}

Other studies on gender and business ownership have generated conflicting evidence on whether or not financing poses problems for women starting and running businesses. The following below are the five challenges:

\subsection{The regulatory environment}

In terms of the regulatory environment, women, particularly black women, were excluded from ownership of property and this had an adverse effect on their ability to access collateral for loan finance. The effect of educational opportunities and systems heavily influenced by societal values and principles, challenged women's choices of careers. The choices from early age have tended towards the softer sciences and not business, science and technology. These choices later affect women's confidence in venturing into the business world or starting businesses, because business has been perceived as a male-dominated world and has been feared (Hendricks, 2004). Women entering the world of business are perceived in a negative way because society still holds women back.

\subsection{Tradition and finance}

Traditional discriminatory practices and lack of information also contribute to black women's inability to accumulate personal assets, which affects their ability to raise loans and the collateral that is required. Therefore, a lack of finance is a major stumbling block to black women entrepreneurs in reaching their full economic potential in South Africa. Despite policy interventions designed to alleviate the constraints in small business sectors, black women entrepreneurs remain on the periphery. Furthermore, black women are in the majority and are continually discriminated against on the basis of race and gender. The majority of these women live in extremely poor conditions and are without education (Magomola, 2000). 


\subsection{Lack of skill and information}

There is a strong need to empower women in general through the use of technology, skills training, and in providing sources of credit to make finance available, since business requires a broad knowledge of financial management to be successful. Market exposure and competitor analysis are, among other things, the prerequisites for businesses to flourish.

\subsection{Discrimination}

Whether women entrepreneurs apply to an institutional financier, a friend, relative or their spouses, they are likely to come against the assumption that "women can't handle money", a concept that is outdated and discriminatory.

\subsection{Lack of proper business track record}

The high rate of illiteracy makes entrepreneurs reluctant to take loans despite the low interest rates, or, again, financial institutions are unwilling to grant loans to entrepreneurs who do not have proper business records.

\section{RESEARCH}

\subsection{Research problem}

The research problem was triggered by the challenges that were faced by the government after the democratic election in 1994. The new government was faced with the eradication of poverty and women's emancipation. Strategic policies to emancipate women became the priority of government. Policies and programmes aimed at eliminating discrimination against women, the disabled and the youth as well as integrating them in the economic mainstream were put in place. It became necessary to investigate financial barriers affecting women entrepreneurs operating in SMMEs. Women constitute $51 \%$ of the population, according to statistics (2011), so side-lining women, and thus leaving the majority of the population behind, would be to the detriment of any government. Therefore bringing them on board in business and politics became the first priority of the South African government in its attempt to eradicate poverty among women. To empower women to participate in business, the Small Business Act No. 106 of 1996 as reviewed in 2003 was put in place. Khula and SEDA were government agencies set up to fasttrack business initiatives. Thus, the study investigated the financial barriers that women, especially black women, face when applying for finance to start and grow businesses. With this in mind the following objectives were set:

\subsection{Objectives}

To investigate the financial barriers facing women entrepreneurs in Tshwane when starting or growing businesses

To establish the obstacles black women entrepreneurs face when applying for financial assistance in Tshwane 


\subsection{Research methodology}

The empirical survey was conducted by means of personal visits, where structured questionnaires were given to the respondents to complete. This study was conducted in the Gauteng Province. Black women entrepreneurs in the city of Tshwane were the target population of the research. A sample of 300 black women entrepreneurs was selected as part of the target population to represent that population. A quota of 50 questionnaires was distributed in each of five townships (Mamelodi, Hammanskraal, Atteridgeville, Ga-Rankuwa and Soshanguve) and the inner city (CBD) of Tshwane. 241 of the questionnaires were returned, yielding a response rate of $80 \%$. The majority of women were between 30 and 49 years old and had gained grade 12 qualifications.

The high response rate of $80 \%$ was achieved because self-administered questionnaires were used and Tshwane is in close proximity to the researcher, which resulted in minimising the cost of travelling. In some cases respondents agreed to fill in the questionnaires immediately. In most cases the questionnaires were left with respondents and collected after completion.

\subsection{Data collection}

Personal and telephonic interviews were conducted randomly from the townships. Where the respondent could not be reached telephonic interviews were the source of data collection.

\subsection{Data processing and analysis}

The SPSS statistical package of the SAS was used to complete the descriptive and inferential statistics. The non-parametric binomial test, chi-square test and ANOVA One Way Analysis of Variance as well as the Post Hoc Test were used to test the reliability of data and significance of the variable groups. To assess construct validity, the 34 opinion questions (on a four-point Likert-Scale) were subjected to a Non-Parametric Binominal Test and Cross-Tabulation test analysis. A statistical technique was used to compare variables between groups.

\section{CHI-SPUARE RESULTS}

The Chi-square method of analysis was used to analyse data, while the $t$-test was used to test whether the hypothesis was accepted or rejected.

The following were found in terms of relationships between the independent variable (women entrepreneurs) and dependent variables:

- Age variable - had a significant relationship: age category of 30-49 had more business experience than women entrepreneurs above fifty years

- Location variable - had a significant relationship: townships closer to government business centres where information is disseminated were more exposed.

- Marital status - had no significant relationship

- Size of business - had a significant relationship: different business categories had different opportunities in terms of access to facilities such as the internet, where government tenders are disseminated. 
Furthermore, investigations of chi-square by means of the post hoc test indicated a significant difference between Grade 12 or N7 and a four-year degree or diploma as well as between a three-year degree or diploma and a four-year degree. Grade 12 or N7 scored significantly higher than a four-year degree or diploma in relation to SEDA training requirements, which indicates that respondents received more training from mentors when starting and growing their business than did respondents in other education categories.

\section{HYPOTHESES}

The following hypotheses were formulated:

- $\mathrm{H}_{1}$ : black women are required by financial institutions and government agencies to provide collateral when applying for finance to start and grow their business.

- $\mathrm{H}_{2}$ : black women entrepreneurs face financial barriers when applying for finance to start and grow their business.

The null hypothesis was accepted for hypotheses 1 and 2, because the $t$-test statistical analysis showed that the level of significance was smaller than .05 $(* p<.05)$.

The chi-square analysis revealed that out of a total of 192 participants who participated in the study 104 applied to start their business using a method of finance other rather than government agencies. $13.92 \%$ applied at the Department of Trade and Industry (DTI). $22.56 \%$ relied on commercial banks. The majority (54.17\%) used their pension funds, and stokvel contributions. Stokvel contributions are monies that women contribute monthly and place into a cooperative account. Once the money and the interest are sufficient, it is distributed to cooperating members, who then start their businesses.

Hypothesis $\mathrm{Hl}$, which reads thus: black women are required by financial institutions and government agencies to provide collateral when applying for finance to start and grow their business, is accepted.

TABLE 1: Chi-square tests on applying for finance and collateral

\begin{tabular}{cccc} 
& Value & $d f$ & Significance (2-sided) \\
\hline Pearson chi-square & $18.354(\mathrm{a})$ & 5 & $0.003 *$ \\
\hline
\end{tabular}

Source: Author's results

$\star p<.05$

The Chi-square analysis indicates that black women entrepreneurs from Mamelodi, the inner city and Hammanskraal were required by government agencies and financial institutions to provide collateral security significantly more than the participants from Atteridgeville, Ga-Rankuwa and Soshanguve. Women in Mamelodi, Hammanskraal and the inner city were more educated and aware of government programmes than the women from other townships. They had access to information and had better financial background to start on their own. Their main type of business was guest houses, and they applied for finance to expand their business. These groups of women were also not successful in getting finance because of collateral and other barriers women face. 


\section{COLLATERAL REPUESTED BY BANKS}

The degree to which respondents were required by financial institutions or government agencies to provide collateral/security is depicted in the table below:

Hypothesis $\mathrm{H} 2$, which reads thus: black women are required by financial institutions and by government agencies to provide collateral when applying for finance to start or grow their business, is accepted.

A Pearson chi-square analysis indicated a significant difference between location, size of the business, years involved in the business, property from where the business is operated and seasonal change in respect of the obtainment of a loan or grant required by financial institution or government agency to provide security/collateral.

TABLE 2: Chi-square tests

\begin{tabular}{cccc} 
& Value & $d f$ & Significance (2-sided) \\
\hline Pearson Chi-Square & $18.354(\mathrm{a})$ & 5 & 0.003 \\
\hline
\end{tabular}

Source: Author's results

$\star p<.01$

A Pearson chi-square analysis indicated a significant difference between location, size of the business, years involved in the business, property from where the business is operated and seasonal change in respect of the obtainment of a loan or grant required by financial institution or government agency to provide security.

The investigations by means of the post hoc $t$-test indicated a significant difference between entrepreneurs with Grade 12 or N7 and a four-year degree or diploma as well as between a threeyear degree or diploma and a four-year degree. Those with Grade 12 or N7 scored significantly higher on mentor training than those with a four-year degree or diploma. Individuals with a three-year degree or diploma scored significantly higher than individuals with a four-year degree or diploma, which indicates that they received more training from mentors when starting and growing their business.

TABLE 3: Chi square test results on tender application

\begin{tabular}{cccc} 
& Value & $d f$ & Asymp. Sig. (2-sided) \\
\hline Pearson chi-square & $28.274(\mathrm{a})$ & 15 & $0.025^{*}$ \\
\hline
\end{tabular}

Source: Author's results

$\star_{p}<.05$

Hypothesis $\mathrm{H} 3$, which states that black women entrepreneurs apply for tenders when starting and growing their business, is rejected. Political connections benefited those women who had close connections with political affiliates and further promoted corruption without benefiting those whom the programmes were intended to empower. 


\section{CONCLUSION}

Successful business owners established their business with their own financing. Their success depended on their ability to obtain business from the public or other businesses. Only a group of guest house owners clearly benefited from government support. This particular group of respondents reported that their support came from the municipal government. The statistical analysis findings revealed that the level of significance for the use of municipal government policies were somewhere between $p<.005$ and $p<.05$.

The results of the inferential statistics (Pearson chi-square analysis) proved that $54 \%$ of the respondents used their own financial resources to establish their businesses. Most black women entrepreneurs have used their own resources to establish their businesses. Of those who did apply for financing, few were successful. The level of significance $p$-value was $p<0.05$. The notion that black women entrepreneurs apply for finance to start and grow business is rejected emanates from the fact that financial institutions maintain that some black women entrepreneurs had poor business records, despite the fact that the government's national strategy no longer applies restricted access to credit facilities. The high rate of illiteracy makes them reluctant to take loans even when interest rates are low. The $p$-values were $<.05$ and $<.01$ respectively. It was concluded that most of the respondents who applied for financing were required to provide collateral.

\section{RECOMMENDATIONS}

The government should conduct a targeted study to develop a thorough understanding of the financial barriers facing black women entrepreneurs, and it should develop initiatives to overcome these specific barriers. Research should be conducted on Khula to investigate why it is not assisting black women to obtain financing from financial institutions. SEDA should provide intensive training to reduce the high levels of illiteracy among black women entrepreneurs. There is also a need to research why black women entrepreneurs are reluctant to take loans even when interest rates are low. The question needs to be asked: what are the reasons financial institutions are reluctant to grant loans to women?

The results indicated that only respondents who operate as medium businesses in certain geographical locations reported that they received tender to grow their business. This did not represent a significant number of respondents: the majority of the respondents were not assisted by tenders to establish their businesses. The chi-square test showed a significant difference in relation to location, age, business size and marital status. The participants from Hammanskraal did not receive any knowledge of tender procurement. The respondents felt that tender documents were very difficult to fill in and were complex and ambiguous. Furthermore, tender documents were not relevant for those who operated small businesses, the empowerment of which was intended to eradicate poverty, but pertained to those operating medium and micro businesses. The participants from Soshanguve, Atteridgeville and the inner city knew about tenders and applied, but none was successful. 


\section{WAY FORWARD}

In order for the City of Tshwane to implement and achieve the desired results in empowering black women entrepreneurs to access finance and overcome financial barriers successfully the following are suggested.

- determine who the target market is

- improve mechanisms for communication

- improve the profile of existing institutions

- feedback mechanisms should be monitored

- arrange workshops for target audience

\section{LIST OF REFERENCES}

Besirika, દ. (1994). Structural Adjustments and the Information Sector in Empowerment. Poverty and Structural Adjustment in Uganda. Edited by J.C. Munene. Kampala: Frederic Ebert Foundation

Brush, C.G. (1992). Research on women business owners: Past trends, a new perspective and future directions. Entrepreneurship Theory and Practice, 16(4), pp. 5-14.

Budlender, D. (1991). Women and the Economy. Johannesburg: Case Offices. Annual Review: State of Small Business Development in S.A.

DTI. (2006). Strategic Framework for Gender and Women's economic empowerment. [Online] Available: http://www.thedti.gov.za/sawen/sawenmain.htm. (Accessed 18 June 2006).

Dollinger, M.J. (1999). Entrepreneurship strategies and resources, $2^{\text {nd }}$ edition. New Jersey: Prentice Hall.

Elson, D. \& Evers, B. (1997). Gender Awareness and Country Economic Reports: Working Paper No 2. Uganda Manchester, United Kingdom.

Hendricks, L. (2001). Organising and mobilising South African entrepreneurs. Unpublished document. Pretoria: The Department of Trade and Industry.

Hendricks, L. (2004). Sustainable job creation through sound investment. SAWEN. Pretoria: The Department of Trade and Industry.

Jiyane, S. (2002). Gender equality and women's participation. Open Society Foundation. South Africa.

King, K. (2003). The international Steering of Education Systems: the case study of the World Bank in the Fields of Work, Education and Occupation. In Oelkers, J. (દd.) Futures of Education. Peter Lang: Bern.

Maas, G. (2007). Global Entrepreneurship Monitor: based on 2006 Report on Women and Entrepreneurship. London: London Business School.

Magomola, N. (2000). African Women Exchange Seminar. Sandton Convention Conference. Johannesburg, South Africa.

Marlow, S. (1992). The Take-Up of Business Growth Training Schemes by Ethnic Minority-Owned Small Firms in Britain. Internationa/ Smal/ Business Journal, 10, pp.34-46. 
Mosala, દ. (2003). Black Economic Empowerment and its implementation by SMMEs. Smal/ Business Monitor, 1, pp. 33.

Mchombu, K. (2000). On Librarianship and poverty. Libri, 32, pp. 241-250.

Naidoo, N. (2012). The state of entrepreneurship in South Africa. [Online] Available:

http://www.fanews.co.za/article.asp?People_and_Companies 12,News 1163,The_state_of_entrepr eneurship_in_South_Africa 12442. (Accessed 14 February 2013).

Nwangha, G.K.N. (1992). Information Needs of Rural Women in Nigeria. Information Development.

Odongo, I.R. (2002). Study of the Information Needs and Uses of the Informal Sector of Uganda. Unpublished PhD Thesis. Durban: University of Zululand.

Sandberg, K.W. (2003). An exploratory study of women in micro enterprises: Gender-related differences. Journal of Small Business and Enterprise Development, 10(4), pp. 408-418.

Small Business Act No.106 (1996). Government Gazette. Vol. 461. Cape Town. RSA.

Standing, G., Sender, J. \& Weeks, J. (1996). Restructuring the South African Labour Market. The S.A challenge. General: LO Office.

Walker, D. \& Joyner, B. (1999). Female Entrepreneurship and the Market Process: Gender-Based Public Policy Considerations. Journal of Development Entrepreneurship, 4(2), pp. 95-116. 
Chiloane-Tsoka 